\title{
Penerapan Mashlahah Mursalah Sebagai Pertimbangan Hakim Dalam Memutus Perkara di Pengadilan Agama
}

\author{
M. Hasbi Umar ${ }^{1 *}$, Muhammad ${ }^{2}$, Warfian Saputra ${ }^{3}$ \\ ${ }^{1,2}$ Pascasarjana UIN Sulthan Thaha Saifuddin Jambi, \\ ${ }^{3}$ Fakultas Hukum Universitas Batanghari \\ *Correspondence email: hasbi_umar@yahoo.com; muhamadpajambi@gmail.com; warfian.koebito@gmail.com
}

\begin{abstract}
Abstrak. Penggunaan mashlahah mursalah sebagai landasan penetapan hukum dikalangan ulama masih diperselisihkan hingga terpecah menjadi dua golongan yaitu golongan yang menggunakan mashlahah mursalah dan golongan yang tidak menggunakan mashlahah mursalah, namun perbedaan pendapat itu tidak berpengaruh kepada hakim peradilan agama di Indonesia, karena terdapat beberapa putusan hakim peradilan agama menerapkan mashlahah mursalah sebagai sandaran pertimbangan dalam putusannya. Hal ini sebagaimana terdapat dalam putusan hakim Pengadilan Agama Jambi dalam Perkara Cerai Gugat Nomor 634/Pdt.G/2019/PA.Jmb, Dispensasi Kawin Nomor 40/Pdt.P/2020/PA.Jmb, dan Isbat Nikah Nomor 14/Pdt.P/2017/PA.Jmb. Hal ini berdasarkan beberapa pertimbangan hukum, yaitu pertama, menggunakan mashlahah mursalah sebagai argumen dan penalaran hukum berdasarkan alat bukti dan fakta-fakta dipersidangan. Kedua, menghidari kemudharatan yang sedang dihadapi oleh para pencari keadilan dengan tujuan untuk mencapai esensi syariat yaitu menjaga agama, jiwa, akal, keturunan, dan harta.
\end{abstract}

Kata Kunci: Mashlahah Mursalah; Pertimbangan; Kemudharatan; Pengadilan Agama.

Abstract. The use of mashlahah mursalah as a basis for legal determination among ulama is still disputed until it is divided into two groups, namely the group that uses mashlahah mursalah and the group that does not use mashlahah mursalah, but the difference of opinion has no effect on religious judges in Indonesia, because there are several decisions of religious judges. Applying mashlahah mursalah as a basis for consideration in his decision. This is as stated in the decision of the Jambi Religious Court judge in the Divorce Case Number 634 / Pdt.G / 2019 / PA.Jmb, Marriage Dispensation Number 40 / Pdt.P / 2020 / PA.Jmb, and Isbat Nikah Number 14 / Pdt. P / 2017 / PA.Jmb. This is based on several legal considerations, namely first, using mashlahah mursalah as argument and legal reasoning based on evidence and facts in court. Second, avoiding the harm that seekers of justice are facing with the aim of achieving the essence of sharia, namely protecting religion, soul, mind, descent and property.

Keywords: Mashlahah Mursalah; Consideration; Kemudharatan; Religious Court

\section{PENDAHULUAN}

Penerapan mashlahah mursalah sebagai dalil-dalil dalam menetapkan hukum dikalangan ulama masih diperselisihkan hingga terpecah menjadi dua golongan yaitu ada golongan mengakui mashlahah mursalah sebagai dalil dalam menetapkan hukum dan ada golongan yang tidak mengakui mashlahah mursalah sebagai dalil dalam menetapkan hukum, ${ }^{1}$ namun perbedaan pendapat dikalangan ulama tidak berdampak kepada hakim peradilan agama di Indonesia. Karena putusan hakim pengadilan agama masih banyak menggunakan metode mashlahah mursalah sebagai pijakan dalam pertimbangannya. ${ }^{2}$

Hal ini sebagaimana diaplikasikan oleh hakim Pengadilan Agama Jambi dalam menerapkan mashlahah mursalah sebagai pertimbangan hukum dalam memutuskan perkara yang diajukan kepadanya. Ada beberapa putusan hakim Pengadilan Agama Jambi menggunakan mashlahah mursalah sebagai pertimbangan hukum dalam putusannya, seperti dalam Perkara Cerai Gugat dengan Nomor 634/Pdt.G/2019/PA.Jmb, Dispensasi Kawin dengan Nomor 40/Pdt.P/2020/PA.Jmb, dan Isbat Nikah dengan Nomor 14/Pdt.P/2017/PA.Jmb.

Oleh karena itu, penulis merasa tertarik untuk menganalisa putusan hakim Pengadilan Agama Jambi yang menggunakan mashlalah mursalah dalam putusannya terhadap perkara Cerai Gugat dengan Nomor 311/Pdt.G/2020/PA.Jmb, Dispensasi Kawin dengan Nomor 40/Pdt.P/2020/PA.Jmb, dan Isbat Nikah dengan Nomor 14/Pdt.P/2017/PA.Jmb. Pertanyaan kemudian adalah pertama, bagaimana hakim Pengadilan Agama Jambi menerapkan mashlahah mursalah dalam putusannya. Kedua, apa faktor penyebab hakim menggunakan mashlahah mursalah sebagai pertimbangan hukum dalam putusannya.

\section{METODE}

Pendekatan penelitian yang digunakan adalah pendekatan penelitian kualitatif, karena penelitian kualitatif merupakan bentuk sebuah penelitian yang dapat mendeskripsikan sebuah kondisi dalam suatu konteks secara

\footnotetext{
${ }^{1}$ Abdul Wahhab Khallaf, Ilmu Ushul Fikih, (Cet. 11, Jakarta: Pustaka Amani, 2003), hlm. 111-115

${ }^{2}$ Abdul Manan, Pembaharuan Hukum Islam di Indonesia, (Jakarta: Kencana, 2017), hlm. 13
} 
mendetail dan mendalam tentang fenomena yang terjadi di lapangan studi, sehingga penelitian ini merupakan lapangan (field research) karena penulis terjun ke lapangan untuk mewawancarai hakim Pengadilan Agama Jambi yang mengadili perkara tersebut. Penelitian ini bersifat deskriptif-analitis, yaitu mendiskripsikan putusan hakim yang menerapkan mashlahah mursalah, kemudian putusan tersebut dianalisa dari data-data hasil wawancara dan prinsipprinsip yang terdapat dalam mashlahah mursalah, yaitu maqashid syari'ah.

\section{HASIL DAN PEMBAHASAN Mashlahah Mursalah}

Untuk memahami kata mashlahah mursalah, akan diartikan satu persatu yang diawali dari kata mashlahah yang berarti manfaat atau terlepas dari kerusakan sedangkan kata mursalah diartikan terlepas dan bebas dari keterangan yang menunjukkan boleh atau tidaknya sesuatu itu dilakukan. ${ }^{3}$ Maka berdasarkan arti dua kata tersebut dapat dipahami bahwa mashlahah mursalah menurut istilah ulama ushul ialah kemashlahatan itu tidak diwujudkan dalam bentuk hukum oleh syari' dan tidak ada dalil syara' yang mengakui atau tidaknya kemashlahatan itu. ${ }^{4}$

Menurut Abdul Karim Zaidan sebagaimana dikutip oleh Romli yang mengemukan bahwa:

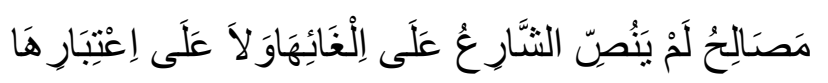

"Mashlahah mursalah adalah mashlahat yang tidak disebutkan oleh nas baik penolakannya maupun pengakuannya". 5

Sehingga menurut Hasbi ash-Shiddieqy sebagaimana dikutip oleh Abdul Manan menyatakan:

"mashlahah mursalah dapat digunakan sebagai dalil hukum kalau mashlahah mursalah itu merupakan mashlahah haqiqiyah yang diakui dan dipandang maslahat oleh ahlul halli wal aqdi bahwa hukum yang dihasilkan itu betulbetul mendatangkan manfaat bagi umat manusia dan benar-benar menolak kemudharatan dari manusia". ${ }^{6}$

Mashlahah mursalah merupakan kemaslahatan yang mempunyai tujuan yang sama dengan syara' untuk menciptakan kemaslahatan bagi manusia serta menghindari dari kemudharatan. ${ }^{7}$ Penggunaan mashlahat mursalah sebagai landasan dalam menetapkan hukum harus berdasarkan tujuan syara' dan tidak berdasarkan hawa nafsu belaka. Adapun tujuan syara' adalah menjaga agama (al-din), jiwa (al-nafs), akal (al-aql), keturunan (al-nasl) dan harta (al$m a l$ ). Maka untuk menetapkan hukum harus mencerminkan kelima aspek tujuan syara' serta menolak segala bentuk kemudharatan yang berkaitan dengan kelima aspek tujuan syara' tersebut. ${ }^{8}$

\section{Pertimbangan Hukum Sebagai Dasar Putusan Hakim}

Adapun yang dimaksud dengan pertimbangan hukum pada dasarnya merupakan sebuah landasan bagi hakim untuk memutuskan perkara yang diajukan kepadanya. selain pertimbangan hukum memuat dasar, alasan dan pertimbangan yang logis-rasional, namun pertimbangan hukum juga memuat pertimbangan lain yang berupa penafsiran maupun kontruksi hukum bagi hakim dalam menghadapi sengketa yang sedang diadilinya. Hendaknya uraian pertimbangan hukum disusun secara sistematis dan komprehensif. ${ }^{9}$

Sehingga pertimbangan hukum merupakan serangkaian dari seluruh tahapan berpikir dari perkara yang diadili guna untuk mendapatkan rasa keadilan bagi para pencari keadilan. Sehingga dengan begitu para pencari keadilan akan memahami dan mengetahui pendapat hakim dalam memutus perkara tersebut. ${ }^{10}$

Pertimbangan hukum bagi hakim bukan hanya saja kepada pencari keadilan, tetapi juga kepada Tuhan Yang Maha Esa. Hakim bertanggung jawab atas putusan dan penetapan yang dibuatnya, tanggung jawab ini akan menjadi perubahan terhadap integritas hakim dalam memutuskan suatu perkara akan berdampak kepada kepercayaan masyarat

\footnotetext{
${ }^{3}$ Sapiudin Shidiq, Ushul Fiqh, (Cet Ke-3, Jakarta: Kencana, 2017), hlm. 88

${ }^{4}$ Abdul Wahhab Khallaf, Ilmu Ushul Fikih, Op.cit., hlm. 110

${ }^{5}$ Romli AS, Pengantar Ilmu Ushul Fiqh Metodologi Penetapan Hukum Islam, (Jakarta: Kencana, 2017), hlm. 198

${ }^{6}$ Abdul Manan, Pembaharuan Hukum Islam di Indonesia, Op.cit., hlm. 178-179

${ }^{7}$ Ibid.

${ }^{8}$ Ahmad Qorib dan Isnaini Harahap, Penerapan Maslahah Mursalah Dalam Ekonomi Islam, Jurnal Analytica Islamica,

${ }^{9}$ M. Natsir Asnawi, Hukum Acara Perdata (Teori, Praktek dan Permasalahannya di Pengadilan Umum dan Pengadilan Agama), (Yogyakarta: UII Press, 2016), hlm. 493-494

${ }^{10}$ Sunarto, Peran Aktif Hakim Dalam Perkara Perdata, Op.cit., hlm. 204
} Vol. 5, No. 1, 2016, hlm. 57 
kepada lembaga peradilan. Tentunya juga didukung oleh argumen hukum yang baik dan benar bagi hakim dalam memutuskan perkara tersebut. ${ }^{11}$

Menurut M. Yahya Harahap sebagaimana dikutip oleh Tim Majalah Peradilan Agama yang menyatakan:

"Pertimbangan hukum merupakan unsur pertama sebuah putusan. Untuk itu, hakim harus paham bagaimana cara dan metode membuat pertimbangan hukum yang baik dan argumentatif. Selain itu, perlu ada pembaharuan cara berpikir hakim dalam menyelesaikan perkara perdata disesuaikan dengan perkembangan hukum yang ada". ${ }^{12}$

Maka atas dasar pendapat tersebut di atas, penulis memandang pentingnya pertimbangan hukum sehingga menjadi "unsur pertama sebuah putusan". Oleh karena itu, hakim dalam merumuskan dan membuat konsep sebuah putusan harus beritegritas dan cerdas sehingga rasa keadilan dan kemanfaatan hukum bisa dirasakan oleh para pencari keadilan.

\section{Penerapan Mashlahah Mursalah Sebagai Pertimbangan Hakim Pengadilan Agama Jambi}

Pada prinsipnya mashlahat mursalah merupakan sesuatu yang baik menurut akal dengan pertimbangan dapat mewujudkan kebaikan atau menghidarkan keburukan bagi manusia. ${ }^{13}$ Prinsip-prinsip ini diterapkan oleh hakim Pengadilan Agama Jambi dalam pertimbangan hukumnya.

Berikut ini pertimbangan hakim Pengadilan Agama Jambi yang menerapkan metode mashlahah mursalah dalam putusannya, adalah sebagai berikut:

\section{Perkara Cerai Gugat dengan Nomor 634/Pdt.G/2019/PA.Jmb}

Adapun duduk perkara singkat, seorang istri mengajukan perkara cerai gugat ke Pengadilan Agama Jambi terhadap suaminya. Dalam gugatan tersebut, pihak istri disebut sebagai penggugat dan pihak suami disebut pihak tergugat, adapun dalil hukumnya adalah rumah tangga antara penggugat dengan tergugat pernah bercerai dan rujuk kembali pada tanggal 23 Mei 2016, namun sejak bulan November 2016 rumah tangga penggugat dengan tergugat tidak berjalan rukun dan harmonis lagi disebabkan antara penggugat dengan tergugat sering terjadi perselisihan dan pertengkaran terus menerus yang mengakibatkan tergugat melakukan kekerasan dalam rumah tangga terhadap penggugat dan tergugat juga mengusir penggugat dari rumah kediaman bersama. ${ }^{14}$

Dalam pemeriksaan perkara, pihak penggugat hadir sendiri dipersidangan sedangkan pihak tergugat telah dipanggil secara patut namun tidak hadir dan tidak menyuruh orang lain untuk hadir sebagai wakilnya hingga agenda pembuktian sehingga pihak tergugat tidak dapat didengar tanggapannya. ${ }^{15}$

Bahwa selama proses persidangan majelis hakim telah berupaya untuk menasehati supaya tidak melanjutkan gugatannya namun pihak penggugat tetap pada dalil-dalil gugatannya untuk bercerai dengan tergugat. Sehingga proses persidangan tetap belanjut, bahkan ke tahap pembuktian dan alat bukti yang diajukan oleh pihak penggugat berupa alat bukti surat dan alat bukti saksi. ${ }^{16}$

Menurut Majelis Hakim Pengadilan Agama Jambi dalam pertimbangan hukum menyatakan:

"Bahwa usaha perdamaian tidak dapat dilakukan karena tergugat tidak hadir di persidangan dan mediasi pun tidak dapat dilaksanakan, namun pengadilan telah memberi nasehat secukupnya kepada penggugat agar bersabar dan menangguhkan niatnya untuk bercerai dengan tergugat, akan tetapi penggugat tetap teguh pada pendiriannya untuk mengajukan perceraian. Sedangkan kehadiran pihak tergugat tidak menjadi halangan yang sah sebab pihak tergugat telah dipanggil secara resmi dan patut". ${ }^{17}$

Majelis hakim kemudian mempertimbangkan berdasarkan gugatan penggugat dan alat bukti yang diajukan baik oleh pihak penggugat saling menguatkan antara satu dengan lainnya. Maka majelis hakim berkesimpulan atas faktafakta dipersidangan menyatakan:

${ }^{11}$ Syarif Mappiasse, Logika Hukum Pertimbangan Putusan Hakim, (Jakarta: Kencana, 2015), hlm. 10-11

${ }^{12}$ Majalah Peradilan Agama, Menyorot Mahkota Hakim Peradilan Agama, Op.cit, hlm. 9-10

${ }^{13}$ Hendri Hermawan dan Mashudi, Al-Maslahat Al-Mursalah Dalam Penentuan Hukum Islam, Jurnal Ilmiah Ekonomi

Islam, 4 (01), 2018, hlm 66 dipublikasikan di http://dx.doi.org/10.29040//jiei.v4i1.140

${ }^{14}$ Berdasarkan salinan putusan perkara dengan nomor 634/Pdt.G/2019/PA.Jmb.

15 Berdasarkan Berita Acara Pesidangan perkara dengan nomor 634/Pdt.G/2019/PA.Jmb.

${ }^{16}$ Berdasarkan Berita Acara Pesidangan perkara dengan nomor 634/Pdt.G/2019/PA.Jmb.

${ }^{17}$ Pertimbangan Majelis Hakim dalam salinan putusan putusan perkara dengan nomor 634/Pdt.G/2019/PA.Jmb. 
"bahwa rumah tangga penggugat dengan Tergugat betul-betul tidak dapat untuk bersatu lagi sebagaimana layaknya suami isteri yang rukun dan damai serta harmonis, dengan demikian tidak adanya harapan akan hidup rukun kembali lagi dalam rumah tangga penggugat dan tergugat dinyatakan terbukti secara sah, sering melakukan kekerasan dalam rumah tangga, memukul, dan menyakiti badan jasmani penggugat". ${ }^{18}$

Berdasarkan hal tersebut, mejelis hakim menilai tujuan perkawinan yang diatur dalam Islam maupun UndangUndang dalam rumah tangga penggugat dengan tergugat telah kehilangan makna dan oleh karenanya demi kepentingan bersama lebih patut dibubarkan. Sebab apabila dipaksakan untuk mempertahankannya maka diduga hal tersebut akan menimbulkan mafsadat yang lebih besar dari pada mashlahatnya, padahal menolak madsadat lebih utama daripada mencapai mashlahatnya sebagaimana kaidah fiqh yang menjadi pertimbangan majelis hakim yang berbunyi:

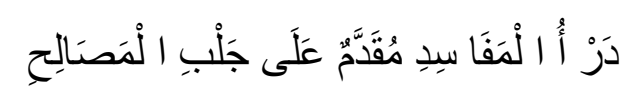

“Menolak kemudaratan lebih didahulukan daripada memperoleh kemashlahatan”.

\section{Perkara Dispensasi Kawin dengan Nomor 40/Pdt.P/2020/PA.Jmb}

Adapun duduk perkara singkat, suami istri mengajukan perkara dispensasi kawin ke Pengadilan Agama Jambi untuk anaknya. Dalam permohonan tersebut, sepasang suami istri tersebut disebut pemohon, kemudian pemohon mengajukan dispensasi kawin untuk anaknya dengan dalil bahwa anak pemohon berencana mau menikah dengan seorang perempuan, namun usia anak pemohon belum mencapai 19 tahun sehingga maksudnya tersebut ditolak oleh Kantor Urusan Agama. ${ }^{19}$

Dalam pemeriksaan perkara, pemohon datang menghadap sendiri ke persidangan, kemudian majelis hakim berupaya untuk menasehati dan memberi pandangan kepada pemohon, anak pemohon yang dimintakan dispensasi kawin, calon istri, dan orang tua calon istri untuk memahami dampak perkawinan dibawah umur, yaitu tentang kemungkinan terjadi kesulitan pembiayaan dalam kehidupan, potensi terjadi perselisihan dan pertengkaran dalam rumah tangga, kekerasan dalam rumah tangga, serta belum siap organ reproduksi anak. namun upaya yang telah dilakukan oleh majelis hakim tersebut tidak berhasil karena pemohon tetap pada permohonannya, bahkan pemohon telah mengajukan alat bukti untuk menguatkan dalil-dalil permohonannya tersebut. ${ }^{20}$

Majelis hakim Pengadilan Agama Jambi dalam pertimbangan hukum menyatakan:

"Bahwa majelis hakim telah memberikan nasihati pemohon, anak pemohon yang dimintakan dispensasi kawin, calon istri, dan orang tua calon istri, namun pemohon dan anak pemohon tetap dengan permohonannya dan majelis telah menimbang alat bukti yang diajukan oleh pemohon dan keterangan dari orang tua calon suami, kesemuanya menguat pemohonan pemohon". ${ }^{21}$

Majelis hakim kemudian mempertimbangkan bahwa anak pemohon sudah sangat berkeinginan untuk menikah, sudah berpacaran dengan calon istri dan pernah melakukan hubungan layaknya suami istri. Sehingga majelis hakim berpandangan perlu segera dinikahkan supaya menghidari perbuatan tersebut terulang lagi. Pendapat majelis hakim sesuai dengan Firman Allah SWT dalam al-Qur'an Surah Al-Nur ayat 32:

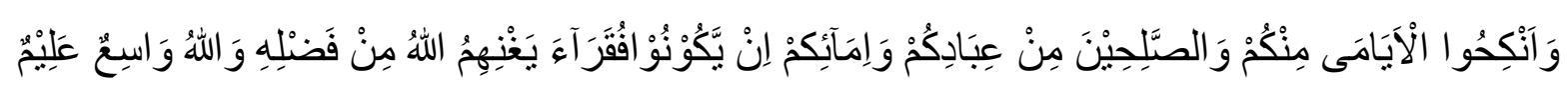

"dan kawinkanlah orang-orang yang sedirian diantara kamu, dan orang-orang yang layak (berkawin) dari hamba-hamba sahayamu yang lelaki dan hamba-hamba sahayamu yang perempuan. jika mereka miskin Allah akan memampukan mereka dengan kurnia-Nya. dan Allah Maha Luas (pemberian-Nya) lagi Maha mengetahui”.

Dalam hal ini hakim juga mengemukan Qaidah Fiqhiyah sebagai berikut:

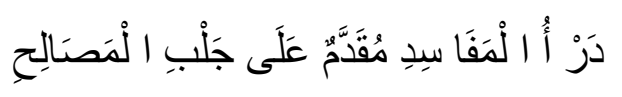

\footnotetext{
${ }^{18}$ Kesimpulan Majelis Hakim dalam salinan putusan putusan perkara dengan nomor 634/Pdt.G/2019/PA.Jmb.

${ }^{19}$ Salinan Penetapan dengan Perkara Nomor 40/Pdt.P/2019/PA.Jmb.

${ }^{20}$ Salinan Penetapan dengan Perkara Nomor 40/Pdt.P/2019/PA.Jmb.

${ }^{21}$ Pertimbangan Majelis Hakim dalam Penetapan Nomor 40/Pdt.P/2019/PA.Jmb.
} 
“Menolak kemudaratan lebih didahulukan daripada memperoleh kemashlahatan”.

\section{Perkara Isbat Nikah dengan Nomor 14/Pdt.P/2017/PA.Jmb}

Adapun duduk perkara singkat, suami istri mualaf mengajukan perkara permohon isbat nikah ke Pengadilan Agama Jambi. Dalam permohonan tersebut, suami istri tersebut disebut pemohon, adapun dalil yang dikemukan oleh pemohon adalah bahwa pemohon pada tanggal 27 Desember 2014 telah melangsungkan pernikahan menurut agama Budha, namun pernikahan pemohon tersebut tidak mendapatkan petikan surat nikah. Kemudian pada tanggal 17 Oktober 2016 pemohon telah memeluk agama Islam sehingga pemohon mengajukan permohonan isbat nikah ke Pengadilan Agama Jambi. ${ }^{22}$

Dalam pemeriksaan perkara, pemohon datang menghadap sendiri ke persidangan dan pemohon telah mengajukan alat bukti untuk menguatkan dalil-dalil permohonannya tersebut. Adapun alat bukti yang diajukan oleh pemohon telah memenuhi syarat formal dan materiil pembuktian. Kemudian majelis hakim dalam pertimbangan hukum menyatakan:

"Bahwa pemohon telah memeluk agama Islam terhitung mulai tanggal 17 Oktober 2016 pernyataan masuk Islam dengan mengucapkan dua kalimat syahadat, maka permohonan isbat nikah pemohon menjadi kewenangan absolut pengadilan agama untuk memeriksa dan mengadilinya". ${ }^{23}$

Majelis hakim Pengadilan Agama Jambi dalam mempertimbangan hukum menyatakan:

"Bahwa pernikahan yang dilakukan berdasarkan agama Budha tidak perlu melakukan nikah ulang karena pernikahan tersebut tetap sah dan tidak perlu lagi nikahnya diperbaharui dengan pernikahan menurut tata cara agama Islam. Pandangan majelis hakim ini merujuk kepada praktik pelaksanaan pada masa Nabi Muhammad SAW telah banyak suami isteri yang masuk Islam dan Nabi Muhammad SAW telah mengesahkan pernikahan mereka sebelum masuk Islam dengan taqrir-nya (persetujuannya), tanpa menanyakan lagi syarat-syarat nikah menurut Islam kepada mereka. Selain itu, majelis hakim mengutip pendapat Imam Asy-Syafii (Al-Umm 5:48) yang berbunyi Apabila ada suami istri yang musyrik, atau penyembah berhala, atau orang Arab beragama Majusi, atau non-Arab yang bukan Bani Israil dan beragama Yahudi atau Nasrani, atau agama musyrik apapun, dan dia bukan Bani Israil, kemudian salah satu masuk Islam, sementara yang lain masih beragama sebelumnya, dan telah terjadi hubungan badan, maka (ketika salah satu masuk Islam) sang suami tidak lagi boleh melakukan hubungan badan dengan istrinya. Dan status nikahnya menggantung selama masa iddah". ${ }^{24}$

Selain itu, Majelis hakim juga mengemukan pendapat Imam Asy-Syafi'i yang berbunyi:

“Jika istri atau suami menyusul masuk Islam, sebelum masa iddah selesai maka status pernikahannnya tidak batal. Namun jika dia baru menyusul masuk Islam setelah masa iddah selesai maka ikatan pernikahan telah putus. Putusnya ikatan pernikahan ini statusnya fasakh dan bukan talak". ${ }^{25}$

Berdasarkan pendapat Asy-Syafii tersebut di atas, majelis hakim berkesimpulan pernikahan non muslim yang menjadi mualaf tetap sah dan tidak perlu melakukan nikah ulang. Melakukan nikah ulang justru menciptakan kekacauan hukum terkait dengan status pemohon. Namun majelis hakim mendapatkan agama yang tertulis di Kartu Tanda Penduduk masih agama Budha, maka dalam hal ini majelis hakim berijtihad hukum dengan tujuan untuk memberikan jalan kemudahan serta menghilangkan kesulitan bagi Pemohon. Dalam hal ini majelis hakim berpegang kepada kaidah fiqh yang berbunyi:

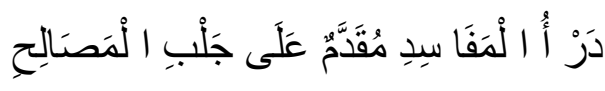

"Menolak kemudaratan lebih didahulukan daripada memperoleh kemashlahatan".

Atas dasar ketiga pertimbangan hukum di atas, hakim Pengadilan Agama Jambi dalam memutuskan Perkara Cerai Gugat Nomor 634/Pdt.G/2019/PA.Jmb, Dispensasi Nikah Nomor 40/Pdt.P/2020/PA.Jmb dan Isbat Nikah

\footnotetext{
${ }^{22}$ Salinan Penetapan dengan Perkara Nomor 14/Pdt.P/2017/PA.Jmb.

${ }^{23}$ Pertimbangan Majelis Hakim dalam Penetapan Nomor 14/Pdt.P/2017/PA.Jmb.

${ }^{24}$ Pertimbangan Majelis Hakim dalam Penetapan Nomor 14/Pdt.P/2017/PA.Jmb

${ }^{25}$ Pertimbangan Majelis Hakim dalam Penetapan Nomor 14/Pdt.P/2017/PA.Jmb
} 
Nomor 14/Pdt.P/2017/PA.Jmb dengan pertimbangan mashlahah mursalah sebagai argumen dan penalaran hukum atas perkara yang diadilinya.

\section{Faktor Penerapan Mashlahah Mursalah Sebagai Pertimbangan Hakim Pengadilan Agama Jambi}

Faktor-faktor yang melatar belakangi penerapan mashlahah mursalah sebagai pertimbangan hakim Pengadilan Agama Jambi adalah untuk menghidari hal-hal yang menimbulkan kemudharatan yang sedang dihadapi oleh para pencari keadilan. Hal ini sebagaimana terdapat dalam putusan hakim Pengadilan Agama Jambi Perkara Cerai Gugat Nomor 634/Pdt.G/2019/PA.Jmb, Dispensasi Nikah Nomor 40/Pdt.P/2020/PA.Jmb dan Isbat Nikah Nomor 14/Pdt.P/2017/PA.Jmb.

Adapun kemudharatan yang dihadapi para pencari keadilan adalah sebagai berikut :

\section{Kemudharatan Dari Kekerasan Dalam Rumah Tangga}

Berdasarkan Perkara Cerai Gugat dengan Nomor 634/Pdt.G/2020/PA.Jmb yang diajukan oleh seorang wanita, dengan berdalil bahwa kehidupan rumah tangga antara penggugat dengan tergugat pernah bercerai dan rujuk kembali pada tanggal 23 Mei 2016, namun sejak bulan November 2016 rumah tangga penggugat dengan tergugat tidak berjalan rukun dan harmonis lagi disebabkan antara penggugat dengan tergugat sering terjadi perselisihan dan pertengkaran terus menerus yang mengakibatkan tergugat melakukan kekerasan dalam rumah tangga terhadap penggugat dan tergugat juga mengusir penggugat dari rumah kediaman bersama. ${ }^{26}$

Sehingga Ketua Mejelis Hakim Pengadilan Agama Jambi berpendapat dalam perkara cerai gugat dengan Nomor 634/Pdt.G/2020/PA.Jmb:

"Bahwa terjadinya perselisihan dan pertengkaran karena sikap tergugat yang kasar dan sering melakukan kekerasan dalam rumah tangga, memukul, dan menyakiti badan jasmani penggugat. Bahwa sikap tergugat sudah tidak mencerminkan sebagai seorang suami yang baik dan bertanggung jawab yang seharusnya memberikan perlindungan dan ketenangan terhadap penggugat sebagai seorang istri". ${ }^{27}$

Maka majelis hakim berkesimpulan bahwa rumah rumah tangganya dipandang tidak layak untuk dipertahankan lagi, mempertahankan rumah tangga dipandangkan akan mendatangkan kemafsadatan (keburukkan) yang lebih besar daripada mashlahatnya. Maka perceraian merupakan jalan keluar untuk menghidari kemudharatan yang dihadapi oleh pihak istri yang telah mengalami kekerasan dalam rumah tangga, apabila diteruskan akan membahayakan keselamatan dan jiwa (al-nafs) pihak istri tersebut. Karena syariat Islam sangat menghargai nyawa seseorang, ${ }^{28}$ meskipun perceraian merupakan sesuatu perbuatan halal yang mempunyai prinsip dilarang oleh Allah SWT. ${ }^{29}$ Berdasarkan hadits Nabi Muhammad SAW, bersabda:

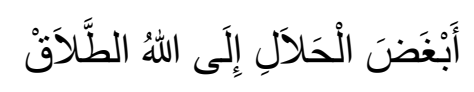

"Sesuatu perbuatan halal yang paling dibenci oleh Allah adalah talak/perceraian". (Riwayat Abu Dawud, Ibn Majah, dan Al-Hakim).

Maka perceraian dalam hukum Islam tidak dapat dihindari, sebab bermacam-macam dinamika rumah tangga manusia tidak kekal sifatnya, meskipun tujuan perkawinan adalah hendak mambangun rumah tangga yang kekal dan bahagia. $^{30}$

\section{Kemudharatan Dari Perbuatan Zina}

Berdasarkan Perkara Dispensasi Nikah Nomor 40/Pdt.G/2020/PA.Jmb, bahwa antara seorang laki-laki dan perempuan berkeinginan untuk menikah, karena antara keduanya telah menjalin hubungan telah lama, bahkan keduanya telah melakukan hubungan layaknya suami istri namun perkawinannya terhalang oleh batas umur belum

${ }^{26}$ Berdasarkan salinan putusan perkara dengan nomor 634/Pdt.G/2019/PA.Jmb.

${ }^{27}$ Wawancara dengan Ketua Majelis atas nama Adwar, pada tanggal 02 Juni 2020

28 Islam sangat menghargai nyawa seseorang dengan adanya acaman qishash menjadi jaminan bahwa tidak boleh menghilangkan nyawa dalam surat al-Maidah ayat 32 dan surah al-Baqarah ayat 179 (lihat di Ahmad Sarwat, Maqashid Syariah, (Jakarta: Rumah Fiqih Publishing, 2019), hlm. 59)

${ }^{29}$ Zainuddin Ali, Hukum Perdata Islam di Indonesia, (Jakarta: Sinar Grafika, 2006), hlm. 73 hlm. 60

${ }^{30}$ Boedi Abdullah dan Beni Ahmad Saebani, Perkawinan Perceraian Keluarga Muslim, (Bandung: Pusaka Setia, 2013), 
mencapai umur 19 tahun sebagaimana ketentuan UU No. 16 Tahun 2019 Tentang Perubahan Atas UU No. 1 Tahun 1974 Tentang Perkawinan.

Maka untuk mencegah terjadinya perbuatan zina lagi, maka hakim mengabulkan permohonan. ${ }^{31}$ Supaya dapat melaksanakan perkawinan berdasarkan syariat Islam dan ketentuan peraturan perundang-undangan. Ini bertujuan untuk menjaga agama (al-din) dan menjaga keturunan (al-nasl). Sebab perkawinan mempunyai nilai ibadah dalam ajaran agama Islam, sehingga Pasal 2 KHI menegaskan bahwa perkawinan adalah akad yang sangat kuat (mitsqan ghalizhan) untuk menaati perintah Allah SWT dan melaksanakannya merupakan ibadah. ${ }^{32}$

Islam mengatur perkawinan untuk dapat mengurangi kemaksiatan, baik dalam bentuk penglihatan maupun dalam bentuk perzinaan. ${ }^{33}$ Sebagaimana firman Allah SWT dalam Surah Al-Isra' Ayat 32:

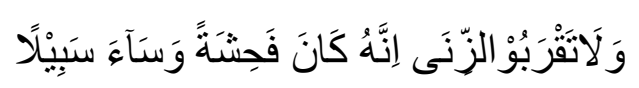

"dan janganlah kamu mendekati zina; Sesungguhnya zina itu adalah suatu perbuatan yang keji. dan suatu jalan yang buruk".

Oleh karena itu, Islam mengatur perkawinan dan mengharamkan perzinaan untuk mewujudkan keturunan yang sehat dan bersih dalam suasana yang tentram dan damai. ${ }^{34}$ Sebagaimana Firman Allah SWT dalam Surah An-Nisa' Ayat 1:

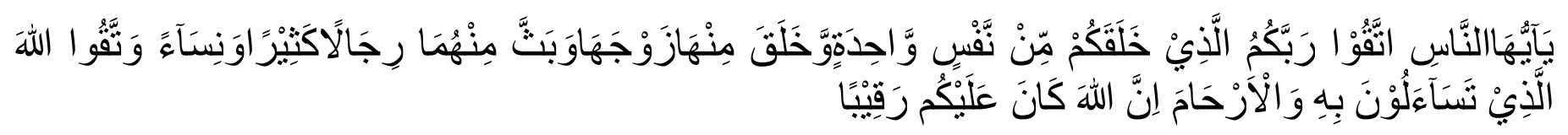

\begin{abstract}
"Hai sekalian manusia, bertakwalah kepada Tuhan-mu yang telah menciptakan kamu dari seorang diri, dan dari padanya Allah menciptakan isterinya; dan dari pada keduanya Allah memperkembang biakkan laki-laki dan perempuan yang banyak. dan bertakwalah kepada Allah yang dengan (mempergunakan) nama-Nya kamu saling meminta satu sama lain, dan (peliharalah) hubungan silaturrahim. Sesungguhnya Allah selalu menjaga dan mengawasi kamu”.
\end{abstract}

\title{
Kemudharatan Dalam Administrasi
}

Dalam Perkara Isbat Nikah dengan Nomor 14/Pdt.P/2017/PA.Jmb, sepasang suami istri telah memeluk agama dan mengajukan perkara pengesahan nikah terhadap perkawinan sebelum memeluk agama Islam ke Pengadilan Agama Jambi. Menurut majelis hakim yang mengadili perkara tersebut, bahwa berdasarkan asas personalitas keislaman, seseorang sudah menjadi mualaf dapat mengajukan perkara ke Pengadilan Agama $^{35}$ karena Pengadilan Agama bertugas dan berwenang untuk memeriksa, memutus, dan menyelesaikan perkara tingkat pertama antara orang-orang yang beragama Islam. ${ }^{36}$

Tetapi dokumen yang dilampirkan dalam bentuk kartu tanda penduduk, kolom agama masih beragama Budha. Sehingga majelis hakim berupaya untuk mencari solusi dan menyelesaikan permasalahan administrasi yang dihadapi oleh sepasang suami istri mualaf tersebut. Maka hakim melakukan ijtihad untuk memberi jalan kemudahan dan menghindari kesulitan yang dihadapi oleh para pencari dengan berpegang kepada kaidah fiqh ${ }^{37}$ :

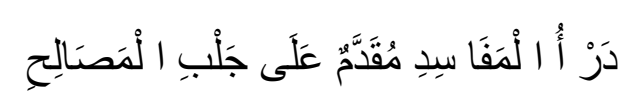

\section{"Menolak kemudaratan lebih didahulukan daripada memperoleh kemashlahatan”.}

Ini bertujuan untuk menjaga kesucian (mitsaqan galidzan) aspek hukum yang timbul dari ikatan perkawinan. ${ }^{38}$ Paling tidak ada dua hal, yaitu menjaga keturunan (hifzb al-nasl) dan menjaga harta (hifzh al-maal). Esensi dari

\footnotetext{
${ }^{31}$ Wawancara dengan Majelis Hakim atas nama Firdaus pada tanggal 28 Mei 2020

${ }^{32}$ Zainuddin Ali, Hukum Perdata Islam di Indonesia, Op.cit., hlm. 7

33 Ibid.

${ }^{34}$ Agil Bahsoan, Mashlahah Sebagai Maqashid Al Syariah (Tinjauan Dalam Perspekstif Ekonomi Islam), Jurnal Inovasi,
} Vol. 8, No. 1, Maret 2011, hlm 117

\footnotetext{
${ }^{35}$ Wawancara dengan hakim Anggota atas nama Sugian Noor pada tanggal 29 Mei 2020

${ }^{36}$ Bunyi Pasal 49 ayat 1 Undang-Undang Nomor 7 Tahun 1989 Tentang Peradilan Agama

${ }^{37}$ Wawancara dengan hakim anggota atas nama M. Nasir pada tanggal 29 Mei 2020

${ }^{38}$ Zainuddin Ali, Hukum Perdata Islam di Indonesia, Op.cit., hlm. 26
} 
pengesahan nikah adalah untuk mendapat akta nikah, yang dapat digunakan untuk mengurus akte kelahiran anak sebagai syarat administrasi di Kantor Catatan Sipil ${ }^{39}$ Selain itu, dengan adanya akta nikah maka masing-masing pihak dapat menggunakannya sebagai syarat administrasi bila ada yang merasa dirugikan dari adanya ikatan perkawinan itu untuk mendapatkan haknya. ${ }^{40}$ Sebagaimana ketentuan Pasal 7 ayat (1) KHI yang berbunyi perkawinan hanya dapat dibuktikan dengan akta nikah yang dibuat oleh pegawai pencatat nikah.

\section{SIMPULAN}

Penerapan mashlahah mursalah sebagai penaran dan argumen hukum dalam putusan hakim Pengadilan Agama Jambi dalam Perkara Cerai Gugat Nomor 634/Pdt.G/2019/PA.Jmb, Dispensasi Nikah Nomor 40/Pdt.P/2020/PA.Jmb dan Isbat Nikah Nomor 14/Pdt.P/2017/PA.Jmb. Ini bertujuan untuk menghindari kemudharatan atau kemafsadatan yang sedang dihadapi oleh para pencari keadilan untuk menjaga kelima aspek tujuan syara', yaitu menjaga agama (aldin), jiwa (al-nafs), akal (al-aql), keturunan (al-nasl) dan harta (al-mal).

\section{DAFTAR PUSTAKA}

Abdullah, Boedi dan Beni Ahmad Saebani, Perkawinan Perceraian Keluarga Muslim, Bandung: Pusaka Setia, 2013

Agama, Majalah Peradilan, Menyorot Mahkota Hakim Peradilan Agama, Edisi 1, Mei 2013

Ali, Zainuddin, Hukum Perdata Islam di Indonesia, Jakarta: Sinar Grafika, 2006

AS, Romli, Pengantar Ilmu Ushul Fiqh Metodologi Penetapan Hukum Islam, (Jakarta: Kencana, 2017

Asnawi, M. Natsir, Hukum Acara Perdata (Teori, Praktek dan Permasalahannya di Pengadilan Umum dan Pengadilan Agama), Yogyakarta: UII Press, 2016

Bahsoan, Agil, Mashlahah Sebagai Maqashid Al Syariah (Tinjauan Dalam Perspekstif Ekonomi Islam), Jurnal Inovasi, Vol. 8, No. 1, Maret 2011

Darmawati, Kewenangan Peradilan Agama, Jambi: Sulthan Thaha Press, 2010

Darmawan, Doni, "Implementasi Peraturan Mahkamah Agung RI Nomor 1 Tahun 2016 Tentang Prosedur Mediasi di Pengadilan", dipublikasi di http://www.pta-jambi.go.id/11-artikel/3870-implementasi-peraturan-mahkamahagung-ri-nomor-1-tahun-2016-tentang-prosedur-mediasi-di-pengadilan, akses 14 Mei 2020

Hermawan, Hendri dan Mashudi, Al-Maslahat Al-Mursalah Dalam Penentuan Hukum Islam, Jurnal Ilmiah Ekonomi Islam, 4 (01), 2018, hlm 66 dipublikasikan di http://dx.doi.org/10.29040//jiei.v4i1.140

Manan, Abdul, Pembaharuan Hukum Islam di Indonesia, Jakarta: Kencana, 2017

Mappiasse, Syarif, Logika Hukum Pertimbangan Putusan Hakim, Jakarta: Kencana, 2015

Qorib, Ahmad dan Isnaini Harahap, Penerapan Maslahah Mursalah Dalam Ekonomi Islam, Jurnal Analytica Islamica, Vol. 5, No. 1, 2016

Sarwat, Ahmad, Maqashid Syariah, Jakarta: Rumah Fiqih Publishing, 2019

Syarifuddin, Amir, Ushul Fiqh, Jilid 2, Cet. Ke-6, Jakarta: Kencana, 2011

Shidiq, Sapiudin, Ushul Fiqh, Cet Ke-3, Jakarta: Kencana, 2017

Sunarto, Peran Aktif Hakim Dalam Perkara Perdata, Cet. 3, Jakarta: Prenadamedia Group, 2019

Wahhab Khallaf, Abdul, Ilmu Ushul Fikih, Cet. 11, Jakarta: Pustaka Amani, 2003

${ }^{39}$ Peraturan Presiden Republik Indonesia Nomor 25 Tahun 2008 Tentang Persyaratan dan Tata Cara Pendaftaran Penduduk dan Pencatatan Sipil dalam Pasal 52 ayat (1) huruf e.

${ }^{40}$ Zainuddin Ali, Hukum Perdata Islam di Indonesia, Op.cit., hlm. 26 